\title{
PERFORMANCE OF LAYING HENS FED WET LAYERS MASH IN A TROPICAL ENVIRONMENT
}

\author{
Hakeem A. Awojobi, Bukola O. Adeola, Adebisi O. Onabajo \\ Department of Animal Production, Olabisi Onabanjo University, Ayetoro Campus, \\ P. M. B. 0012, Ayetoro, Ogu n State, Nigeria. \\ hakeem.awojobi@oouagoiwoye.edu.ng
}

\begin{abstract}
A b s t r a c t: This study was conducted to assess the performance of laying hens fed wet layers mash in a tropical environment. A total of sixty, 29 weeks old Nera black hens were used. The experimental treatments are: conventional dry mash with (D), Wet mash; 1 part of feed to 0.5 part of water (W0.5), Wet mash; 1 part of feed to 1 part of water (W1.0), Wet mash; 1 part of feed to1.5 parts of water (W1.5). The birds were offered $125 \mathrm{~g}$ of feed/bird/day and drinking water free choice. Wetting of feed was done at the time of feeding. The study was conducted in two phases. In Study 1 , the birds were fed a proprietary layers mash. After 6 weeks, the experiment was repeated using a lower crude protein diet which formed the second phase of the study. Data were collected on feed intake, percentage hen day, feed conversion and internal and external egg quality attributes. The results in studies 1 and 2 showed that Nera black feed intake was significantly $(\mathrm{P}<0.05)$ higher in laying hens that received wet mash. Percentage hen day and was lower $(\mathrm{P}<0.05)$ and feed conversion ratio higher $(\mathrm{P}<0.05)$ in the $\mathrm{W} 1.0$ and $\mathrm{W} 1.5$ groups than the $\mathrm{W} 0.5$ and the dry mash group. The findings also showed that egg weight, egg length, egg width, shell thickness, yolk height, albumen height, yolk width, yolk weight and haugh unit were not significantly $(\mathrm{P}>0.05)$ different. Overall performance was comparable in birds fed dry mash and bird on 1 part of feed to 0.5 part of water in both studies.
\end{abstract}

Key words: dry mash; laying hens; layers mash; performance; wet mash

\section{ПРОИЗВОДНИ КАРАКТЕРИСТИКИ НА КОКОШКИ НЕСИЛКИ ХРАНЕТИ СО ВЛАЖНА СМЕСКА ВО ТРОПСКИ УСЛОВИ}

\begin{abstract}
А п с т р а к т: Оваа студија беше спроведена за да се оценат производните перформанси на кокошки несилки, кои се хранети со влажна смеска во тропски услови. Биле користени шеесет кокочки несилки на возраст од 29 недели Nera black кокошки. Експерименталните третмани се: со конвенционална смеска (Д), влажна смеска; 1 дел од крмна смеска на 0,5 дел вода (W0.5), влажна смеска; 1 дел од крмна смеска на 1 дел вода (W1.0), влажна смеска; 1 дел крмна смеска со1,5 делови вода (W1.5). На птиците им беше понудено $125 \mathrm{~g}$ добиточна храна / птица / ден и слободен избор за вода за пиење. Влажнењето на добиточната храна беше правено во време на хранењето. Студијата беше спроведена во две фази. Во студијата 1, несилките добиваа влажна смеска. После 6 недели, експериментот беше повторен со употреба на диета со понизок ниво на сурови протеини, што ја формираше втората фаза од студијата. Податоците беа собрани за внесот на добиточна храна, процент на ден по кокошка, конверзија на добиточна храна и внатрешни и надворешни карактесристики за квалитет на јајцата. Резултатите од студиите 1 и 2 покажаа дека внесот на храна беше сигнификантпо $(\mathrm{P}<0,05)$ повисок кај кокошките кои добивале влажна смеска. Процент на кокошка на ден беше понизок $(\mathrm{P}<0,05)$ и односот на конверзија на добиточна храна повисок $(\mathrm{P}<0.05)$ во групите W1.0 и W1.5 во споредба со W0.5 и групата која добиваше сува смеска. Наодите исто така покажаа дека тежината на јајцето, должината на јајцето, обемот на јајцето, дебелината на лушпата, висината на жолтокот, висината на белтокот, ширината на жолтокот, тежината на жолтокот и Хофовите единици не беа значително различни $(\mathrm{P}>0.05)$..
\end{abstract}

Клучни зборови: сува смеска; кокошки несилки; производни карактеристики; влажна смескав

\section{INTRODUCTION}

Various effort have been made on the improvement of the level of feed intake, growth, egg pro- duction, egg quality and feed conversion efficiency of poultry through genetic manipulation, use of feed additives either as a pharmaceutical or nutriceuticals and management practices.Recently, dietary studies 
have shown that wet feeding could be of benefit in increasing poultry performance (meat and egg) particularly under high environmental temperature. Although in Great Britain, poultry have traditionally been fed on wet mash, this practice has not been adopted under Large-Scale Intensive production because it has not been thought to confer any definitive advantage, Studies by Yalda and Forbes (1995) and Awojobi and Meshioye (2001) is pointing to the tendency that wet mash have advantages over dry mash feeding in broiler production and cockerel of an egg laying strain (Ogbonna et al., 2001; Awojobi et al., 2009). Similar results have been observed in laying hens ( Kutlu and Forbes 1992), Japanese quail layers and ducks (Yalda and Forbes 1993).

In Nigeria, poultry diets are normally fed as dry mash. Wet mash-feeding involves the addition of water to dry poultry feed before feeding. Wet feeding has been reported to improve egg production, egg weight and food efficiency (Thorne et al. 1989). Tadtiyanant et al. (1990) reported that dry matter intake of layers maintained at high environmental temperature could be improved by wet feeding with diet containing 50\% moisture. Kutlu et al. (1995) reported that a diet containing more than $60 \%$ moisture increased performance of layers under heat stress conditions.

Currently, there's a dearth of information on the desirability or otherwise of wet mash feeding in laying birds in the tropics. Most trials have been carried out under temperate conditions, such trials have become necessary so that we would predetermine whether the tropics can benefit from the aforementioned arguments. This study was therefore aimed to evaluating the performance of laying hens fed wet layers mash in a tropical environment.

\section{MATERIALS AND METHODS}

\section{Experimental location}

The experiment was conducted at Teaching and Research Farm, College of Agriculture Sciences, OlabisiOnabanjo University, Ayetoro Campus, Ogun State, Nigeria. The university campus is located in a derived savannah zone of Nigeria at latitude $7^{0} 15^{\prime} \mathrm{N}$ and longitude $3^{0} 3^{\prime} \mathrm{E}$. Climate is subhumid tropical with an annual rainfall of 1,909.3 $\mathrm{mm}$. Rainy season is between early April and late October. Rainfall pattern is bimodal with two peaks in June and September. Maximum temperature varies between $29^{\circ} \mathrm{C}$ during the peak of and $34^{\circ} \mathrm{C}$ at the onset of the wet season and mean annual relative humidity is $81 \%$ (Onakomaiya - 1992).

\section{Experimental Birds}

Sixty Nera Black hens at 27 weeks of age were obtained from a reputable source. They were raised using the battery cage system and fed a proprietary layers mash in the dry form during an acclimatization period of two weeks. All management practices were carried out appropriately.

\section{Experimental Trial}

The experimental was conducted in two phases, and each phase lasted for 6 weeks. Initial and Final weight of the birds was taken separately for each of the phases. Random allocation of experimental animals to treatments was also carried out before the commencement of each of the phases.

\section{Study 1: Performance of laying hens fed a propri- etary mash in the wet and dry forms}

At the twenty nine weeks of age sixty birds were randomly allocated to experimental treatments after taking their initial live weight. There were four (4) treatment. Each replicated five (5) times, with three (3) birds per replicates. The birds were fed a proprietary layers mash containing: Energy 2550 $\mathrm{kcal} / \mathrm{kg}$, CP $16.5 \%$, Ca 3.5\%, EE 3.5\%, CF 6\%

The experimental treatments are:

- Dry mash with drinking water (D).

- Wet mash (1 part of feed to 0.5 part of water) with drinking water (W0.5).

- Wet mash (1 part of feed to 1 part of water) with drinking water (W1.0).

- Wet mash (1 part of feed to 1.5 part of water) with drinking water (W1.5).

The birds were offered $125 \mathrm{~g}$ of feed/bird/day and drinking water free choice. Wetting of feed was done at the time of feeding and feeding was done twice daily.

\section{Data collection}

Feed intake, egg production with respect to egg number, and egg weight were carried out on a daily basis. After four weeks, sixty (60) eggs from each treatment was assessed for quality and data that were taken includes; egg weight $(\mathrm{g})$, egg length $(\mathrm{cm})$, egg width $(\mathrm{cm})$, egg volume $(\mathrm{ml})$, yolk height $(\mathrm{cm})$, yolk width $(\mathrm{mm})$, Albumen height $(\mathrm{cm})$, yolk weight $(\mathrm{g})$, shell weight $(\mathrm{g})$, shell thickness $(\mathrm{mm})$, haugh unit, specific gravity, percentage hen day 
production, feed conversion ratio, and live weight gain of birds.

\section{Study 2: Performance of laying hens fed a lower crude protein diet in the wet and dry forms}

At thirty five weeks of age, the birds were reweighed and randomly allocated to experimental treatments. There were four (4) treatments in all. Each treatment was however replicated four (4) times and there were three (3) birds per replicate. The experimental diet in study 2 contained; $\mathrm{CP}$ $14.7 \%$, Energy $2581.25 \mathrm{kal} / \mathrm{kg}$, EE $3.73 \%$, CF $4.58 \%$, Lysine $0.582 \%$, Methionine $0.2 \%$, Ca $3.565 \%, \mathrm{P} 0.29$.

The birds were offered $125 \mathrm{~g}$ of feed/bird/day and drinking water free choice. Wetting of feed was done at the time of feeding. Data collection was as carried out as in study 1 .

\section{EXPERIMENTAL DESIGN AND DATA ANALYSIS}

All data collected were subjected to analysis of variance for a completely randomized design using SAS (2000).The mean of significant measurement was compared using Duncan's multiple range test of the same statistical software.

\section{RESULTS AND DISCUSSION}

Table 1 shows the overall live performance of Nera Black breed fed proprietary layers mash in the dry and wet forms for a period of six weeks. Final live weight, weight gain, average egg weight and mortality were not significantly $(\mathrm{P}>0.05)$ affected by experimental treatments. Feed intake was higher in wet fed birds being significantly $(\mathrm{P}<0.005)$ higher in birds in the $\mathrm{W}^{1.0}$ and $\mathrm{W}^{1.5}$ groups than birds on dry mash. This result agrees with the report of higher feed intake in wet-fed than dry-fed broilers (Abasiekong, 1989; Yalda and Forbes, 1995 and Awojobi and Meshioye, 2001), cockerels (Ogbonna et al., 2001 and Awojobi et al., 2007) and layers (Tadtiyanant et al., 1991). Percentage hen day and feed intake per unit egg weight (FCR) were similar in the dry fed and $\mathrm{W}^{0.5}$ groups being significantly $(\mathrm{P}<0.05)$ better than layers in the $\mathrm{W}^{1.0}$ and $\mathrm{W}^{1.5}$ experimental treatments. This result is contrary to the findings of Thorne et al. (1989) and Kutlu et al. (1995) who reported better performance for laying birds on wet mash. However birds that received 1 part of feed to 0.5 partof water $\left(\mathrm{W}^{0.5}\right)$ had a better
$(\mathrm{P}>0.05)$ FCR (3.07) than dry mash fed layers (3.09).

Table 1

Live performance of Nera Black breed fed proprietary layers mash in the dry and wet forms for a period of six weeks.

\begin{tabular}{|c|c|c|c|c|c|}
\hline Variable & $\mathrm{D}$ & $\mathrm{W}^{0.5}$ & $\mathrm{~W}^{1.0}$ & $\mathrm{~W}^{1.5}$ & SEX \\
\hline $\begin{array}{l}\text { Initial live } \\
\text { weight (kg) }\end{array}$ & 1.57 & 1.57 & 1.55 & 1.55 & 0.03 \\
\hline $\begin{array}{l}\text { Final live } \\
\text { weight }(\mathrm{kg})\end{array}$ & 1.57 & 1.67 & 1.67 & 1.62 & 0.05 \\
\hline Weight gain $(\mathrm{g})$ & 2.00 & 102.00 & 114.00 & 70.00 & 58.15 \\
\hline $\begin{array}{l}\text { Feed intake } \\
(\mathrm{g}) / \text { day }\end{array}$ & $117.38^{\mathrm{b}}$ & $123.57^{\mathrm{ab}}$ & $125.00^{\mathrm{a}}$ & $125.00^{\mathrm{a}}$ & 3.29 \\
\hline Hen day (\%) & $73.6^{\mathrm{a}}$ & $77.18^{\mathrm{a}}$ & $61.22^{\mathrm{b}}$ & $63.74^{\mathrm{b}}$ & 3.23 \\
\hline $\begin{array}{l}\text { Mean egg } \\
\text { weight (kg) }\end{array}$ & 51.55 & 52.14 & 56.43 & 55.95 & 0.13 \\
\hline FCR & 2.47 & 2.19 & 2.37 & 2.35 & 0.06 \\
\hline Mortality (\%) & - & 0.06 & - & 0.06 & 0.0001 \\
\hline
\end{tabular}

${ }^{a b}$ Means on the same row with different superscripts are significantly $(\mathrm{P}<0.05)$ different.

Table 2 shows the result of external egg quality assessment in laying hens fed proprietary layers mash in the wet and dry forms. Average egg weight, egg length, egg width, specific gravity, shell weight and shell thickness were not significantly $(P>0.05)$ influenced by wet feeding just as reported by Kutlu (1995). Egg volume was significantly $(\mathrm{P}<0.05)$ higher in birds that received dry feed than those on W1.5. This was attributed to the egg weight. Egg weight is directly proportional to the egg volume.

\section{Table 2}

\section{External Egg Quality Assessment in Laying Hens Fed Proprietary Layers Mash in the Wet} and Dry Forms.

\begin{tabular}{lccccc}
\hline Variable & $\mathrm{D}$ & $\mathrm{W}^{0.5}$ & $\mathrm{~W}^{1.0}$ & $\mathrm{~W}^{1.5}$ & $\mathrm{SEX}$ \\
\hline Egg weight $(\mathrm{g})$ & 57.75 & 56.63 & 57.52 & 57.09 & 1.40 \\
Egg length $(\mathrm{cm})$ & 5.49 & 5.25 & 5.74 & 5.16 & 0.23 \\
Egg width $(\mathrm{cm})$ & 4.18 & 3.77 & 3.87 & 3.62 & 0.18 \\
Egg volume $(\mathrm{ml})$ & $38.46^{\mathrm{a}}$ & $32.62^{\mathrm{ab}}$ & $32.40^{\mathrm{ab}}$ & $30.66^{\mathrm{b}}$ & 2.29 \\
Shell thickness $(\mathrm{mm})$ & 0.390 & 0.398 & 0.394 & 0.390 & 0.00 \\
Specific gravity & 1.08 & 1.08 & 1.08 & 1.082 & 0.00 \\
Shell weight $(\mathrm{g})$ & 5.67 & 5.72 & 6.04 & 5.24 & 0.00 \\
\hline
\end{tabular}

${ }^{a b}$ Means on the same row with different superscripts are significantly $(\mathrm{P}<0.05)$ different. 
The results of internal egg quality assessment of laying hens fed proprietary layers mash in the wet and dry forms for a period of six weeks is presented in Table 3. Yolk height, albumen height, yolk width, yolk weight and haugh unit did not show any significant $(\mathrm{P}>0.05)$ difference. There was significant $(\mathrm{P}<0.05)$ difference in yolk colouration. Kaseh and Forbes (1992) reported that shell colour, yolk colour and albumen height were improved by wet feeding. Similar result in terms of yolk colouration was observed in this study.

Table 3

Internal Egg Quality Assessment in Laying Hens Fed Proprietary Layers Mash in the Wet and Dry Forms.

\begin{tabular}{lccccc}
\hline \hline Variable & D & $\mathrm{W}^{0.5}$ & $\mathrm{~W}^{1.0}$ & $\mathrm{~W}^{1.5}$ & $\mathrm{SEX}$ \\
\hline Yolk height $(\mathrm{cm})$ & 1.46 & 1.36 & 1.46 & 1.49 & 0.07 \\
Albumen height $(\mathrm{cm})$ & 0.68 & 0.64 & 0.59 & 0.64 & 0.00 \\
Yolk width $(\mathrm{cm})$ & 4.06 & 4.21 & 4.12 & 4.10 & 0.08 \\
Yolk weight $(\mathrm{g})$ & 14.55 & 15.13 & 14.17 & 13.98 & 0.57 \\
Yolk colouration & $8.01^{\mathrm{b}}$ & $9.15^{\mathrm{a}}$ & $9.42^{\mathrm{a}}$ & $8.20^{\mathrm{a}}$ & 0.37 \\
Haugh unit & 89.36 & 84.64 & 85.88 & 97.59 & 9.60 \\
\hline \hline \\
$\begin{array}{l}\text { ab Means on the same row with different superscripts are significantly } \\
(\mathrm{P}<0.05) \text { different. }\end{array}$
\end{tabular}

Table 4 shows the mean overall live performance of laying hens fed a lower crude protein diet in the wet and dry forms. Weight gain and mean egg weight were not significantly $(\mathrm{P}>0.05)$ different. A decrease in body of birds weight was observed in all the treatments. The reduction in weight of the birds may be attributed to the lower crude protein diet. Feed intake was significantly $(\mathrm{P}<0.05)$ higher in birds that received wet mash. Feed intake also increases as water additions to diets increases. This is similar trend to what was observed in study one.The highest hen day percentage was observed in $\mathrm{W}^{0.5}$ and is statistically similar to that of birds on dry mash feeding. Birds in the $\mathrm{W}^{1.0}$ and $\mathrm{W}^{1.5}$ group has a lower $(\mathrm{P}<0.05)$ percentage hen day than the dry fed and $\mathrm{W}^{1.5}$ groups. This is similar to what was observed in Study 1. The highest hen day percentage was observed in $\mathrm{W}^{0.5}$ and is statistically similar to that of birds on dry mash feeding. Birds in the $\mathrm{W}^{1.0}$ and $\mathrm{W}^{1.5}$ groups had a lower $(\mathrm{P}<0.05)$ percentage hen day than the dry mash fed and $\mathrm{W}^{0.5}$ groups. This is similar to the trend observed in Study 1 . The possible effects of wet feeding causing increased activation of endogenous enzymes and increasing dry matter and protein digestibility as reported by Fry et al. (1958) is not supported by the current findings.

\section{Table 4}

Mean Overall Live Performance of Laying Hens Fed a Lower Crude Protein Diet in the Wet and Dry Forms.

\begin{tabular}{lccccc}
\hline \hline Variable & $\mathrm{D}$ & $\mathrm{W}^{0.5}$ & $\mathrm{~W}^{1.0}$ & $\mathrm{~W}^{1.5}$ & $\mathrm{SEX}$ \\
\hline Weigt gain (g) & 110 & 90 & 60 & 110 & 37.00 \\
$\begin{array}{l}\text { Feed intake } \\
\text { (g/day) }\end{array}$ & $104.69^{\mathrm{c}}$ & $118.36^{\mathrm{b}}$ & $124.83^{\mathrm{a}}$ & $125.00^{\mathrm{a}}$ & 0.83 \\
FCR & $3.04^{\mathrm{c}}$ & $3.41^{\mathrm{bc}}$ & $3.77^{\mathrm{ab}}$ & $4.11^{\mathrm{a}}$ & 0.28 \\
Hen day (\%) & $68.75^{\mathrm{a}}$ & $71.50^{\mathrm{a}}$ & $65.00^{\mathrm{b}}$ & $58.00^{\mathrm{b}}$ & 2.52 \\
$\begin{array}{l}\text { Mean egg weight } \\
\text { (g) }\end{array}$ & 50.07 & 48.47 & 50.85 & 46.7 & 5.48 \\
\hline \hline
\end{tabular}

Table 5 shows the results of external egg quality assessment in laying hens fed a lower crude protein diet in the wet and dry forms. No significant $(\mathrm{P}>0.05)$ differences were observed in egg length, egg width, egg volume, shell weight, shell thickness and specific gravity. The highest $(\mathrm{P}>0.05)$ egg length was observed in $\mathrm{W}^{1.0}$. Though not significantly different $(\mathrm{P}>0.05)$, egg width, egg volume and shell thickness were higher in birds that received dry mash.

\section{Table 5}

\section{External Egg Quality Assessment in Laying Hens Fed a Lower Crude Protein Diet in the Wet and Dry Forms}

\begin{tabular}{|c|c|c|c|c|c|}
\hline Variable & $\mathrm{D}$ & $\mathrm{W}^{0.5}$ & $\mathrm{~W}^{1.0}$ & $\mathrm{~W}^{1.5}$ & SEX \\
\hline Egg weight (g) & 58.20 & 56.27 & 54.96 & 60.00 & 1.30 \\
\hline Egg length(cm) & 5.49 & 5.47 & 5.66 & 5.20 & 0.21 \\
\hline Egg width $(\mathrm{cm})$ & 4.51 & 4.12 & 4.19 & 4.12 & 0.15 \\
\hline Egg volume (ml) & 38.634 & 33.57 & 38.30 & 34.49 & 2.15 \\
\hline Shell thickness (mm) & 0.362 & 0.316 & 0.353 & 0.353 & 0.00 \\
\hline Specific gravity & 1.07 & 1.07 & 1.07 & 1.07 & 0.00 \\
\hline Shell weight (g) & 4.69 & 4.56 & 4.68 & 4.67 & 0.00 \\
\hline Average egg weight $(\mathrm{g})$ & 58.20 & 56.27 & 54.96 & 60.00 & 3.42 \\
\hline
\end{tabular}


The internal egg quality assessment results in laying hens fed a lower crude protein diet in the wet and dry forms is presented in Table 6. Yolk height, albumen height, yolk width, yolk weight, yolk colouration and haugh unit were not significantly different $(\mathrm{P}>0.05)$ among treatments. The significant variation that was observed in yolk colouration in Study 1 when the birds were fed a proprietary layers mash in the wet and dry forms was not observed in Study 2. The haugh unit (Haugh,1937), an expression relating egg weight to height of thick albumen is the most widely used method in determining albumen quality. The higher the haugh unit, the better the egg quality. This implies more quality eggs $(\mathrm{P}>0.05)$ were obtained from laying hens that received wet feed with higher values for haugh unit.

\section{Table 6}

\section{Internal Egg Quality Assessment in Laying Hens Fed a Lower Crude Protein diet in the Wet and Dry Forms.}

\begin{tabular}{lccccc}
\hline \hline Variable & D & W 0.5 & W 1.0 & W 1.5 & SEX \\
\hline Yolk height $(\mathrm{cm})$ & 1.53 & 1.47 & 1.56 & 1.51 & 0.05 \\
Albumen height $(\mathrm{cm})$ & 0.64 & 0.63 & 0.67 & 0.69 & 0.05 \\
Yolk width $(\mathrm{cm})$ & 4.09 & 4.03 & 4.04 & 4.07 & 0.05 \\
Yolk weight $(\mathrm{g})$ & 15.25 & 14.01 & 14.71 & 14.37 & 0.64 \\
Yolk colouration & 5.81 & 5.61 & .69 & 6.13 & 0.31 \\
Haugh unit & 80.36 & 80.56 & 82.18 & 82.88 & 3.25 \\
\hline \hline
\end{tabular}

${ }^{\mathrm{ab}}$ Means on the same row with different superscripts are significantly $(\mathrm{P}<0.05)$ different.

\section{CONCLUSION}

From the study, there is no significant advantage to be derived from wet feeding of laying hens in the experiment except for a better yolk colouration obtained in study 1. Compensation for the reduction in crude protein content of layers mash was not enough, even though a higher feed intake was observed in wet fed birds. These findings are contrary to research reported by trials under temperate conditions.

Laying bird production can only benefit from wet feeding to the extent of the addition of 1 part of feed to 0.5 part of water which largely have a comparable performance with dry mash feeding.

\section{REFERERENCES}

Abasiekong, S.F.: Seasonal effect of wet rations on performance of broiler poultry in the tropics. Achieve Animal Nutrition, Berlin, vol. 39, pp. 507-514 (1989)

Awojobi, H.A., Meshioye, O.O.: A comparison of wet mash and dry mash feeding for broiler finisher during wet season in the tropics. Nigerian Journal of Animal Production, Vol. 28, No. 2, pp. 143-146 (2001).

Awojobi, H. A., Oluwole, B. O., Adekunmisi, A. A., Buraimo R. A.: Performance of finisher broilers fed wet mash with or without drinking water during wet season in the tropics. Int. J. Poult. Sci. Vol.8, pp. 592-594 (2009).

Duncan, D. B.: New Multiple Range Test. Biometrics vol. 11, pp. 1-42 (1955)

Fry, R. E., Alfred, J. B., Jensen, L.. S., McGinnis.: Influence of enzymes supplementation and water treatment on the nutritional value of different grains for poultry. Poultry Science, vol. 37, pp. 372-375 (1958).

Haugh, R. R.: The Haugh unit for measuring egg quality U.S. Egg Poult.Magaz. vol. 43, pp. 555-573 (1973)

Kaseh, R. E. L and Forbes, J. M.: Effect of wet food on the performance of laying hens. British Poultry Science vol. 36, pp. 839-840 (1992).

Kutlu, H. R., Ozturkan, O., Baykal, L., Celik, K..: Effect of moisture content of the diet on performance and egg quality of laying hens at high environmental temperature. Proceeding of International poultry congress '95' Istanbul Turkey, pp. 163-172 (1995).

Ogbonna, J. U, Ogundola, F. I., Oredein, A.O.: Effect of wet feed on cockerel chicken performance. Nigeria journal of Animal Production vol. 28, No1, pp. 52-55 (2001)

Onakomaiya, S. O., Oyesiku, K. A., Jegede, S. J.: Ogun state in Maps. First ed. Rex. Charles Publication, Ibadan, 1992.

Tadtiyanant, C., Lyons, J. J., Vanderpopuliere, J. M.: Influence of wet and dry feed on laying hens under heat stress. Poult. Sci. 70, pp. 44-52 (1991).

Thorne, D. H., Vanderpopuliere, J. M., Lyons, J. J.: Automated high moisture diet feeding system for laying hens. J. World Poult. Sci. 68, pp. 1114-1117 (1989).

Williams, C.: Some factors affecting albumin quality with particular reference to Haugh Unit Score. World Poultry Science Journal Vol. 48, pp. 5-16 (1992).

Yalda, A. Y., Forbes J. M.: Effect of wet feeding on the growth of ducks. British Poultry Science vol. 36, pp. 878-879 (1993).

Yalda, A. Y., Forbes J. M.: Food intake and growth chickens gives food in wet form or without access to drinking water. British poultry Science vol. 36, pp. 357-369 (1995). 
